\title{
Okulöncesi Eğitimi Fen Etkinliklerinde Doğa Olaylarının Neden Sonuç İlişkilerini Belirlemede Yaratıcı Dramanın Etkililiği
}

\author{
Elif ERKOCA AKKÖSE ${ }^{1}$
}

Milli Eğitim Bakanlı̆̆

\begin{abstract}
$\ddot{O} z e t$
Okulöncesi fen etkinliklerinde doğa olaylarının neden sonuç ilişkilerini belirlemede yaratıcı dramanın etkililiğini belirlemeye yönelik yapllan bu araştırma, deneme modellerinden kontrollü öntest sontest modele göre gerçekleştirilmiştir.Araştırma deney grubunda 14, kontrol grubunda 14 olmak üzere toplam 28 tane 6 yaşındaki çocuk üzerinde yürütülmüş̧ür. Araştırmada veri toplama aracı olarak araştırmacı tarafindan geliştirilen bilgi formu, video ve etkinlik materyalleri kullanılmıştır. Elde

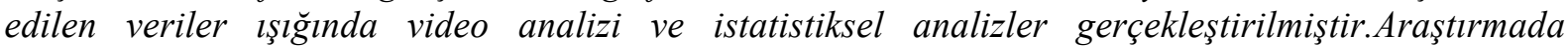
deneklerin öntest ve sontest puanlarına ilişkin yüzde ve frekans hesaplaması deneklere ilişkin yapılan video analizlerinden elde edilmiştir. Ayrıca deneklerin öntest ve sontest puanlarına ilişsin standart sapma ve aritmetik hesaplamasının yapıldĭ̆ betimsel istatistiksel analizler ile deney ve kontrol grubundan elde edilen puanlar arasındaki farkın anlamlı olup olmadı̆̆ "Mann-whitney-U" testi ile istatistiksel analiz yapılmıştır. Yapılan istatistiksel analizler SPSS 11,5 programı ile bilgisayar ortamında gerçekleştirilmiştir. Yapılan video kayıt analizi ve istatistiksel analizlerle elde edilen bulgular şu şekilde özetlenebilir. Okulöncesi eğitimi fen etkinliklerinde öğretim

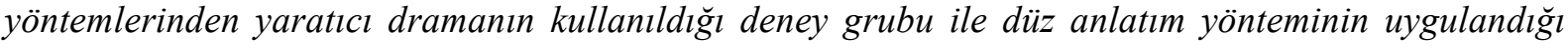
kontrol grubundaki öğrencilerin doğa olaylarının neden sonuç ilişkilerini belirleme becerileri arasında deney grubu lehine anlamlı bir fark vardır. Bir başka deyişle, yaratıcı dramanın kullanımı, çocukların fen etkinliklerinde doğa olaylarının neden sonuç ilişkilerini belirleme becerilerini gelişstirmektedir.
\end{abstract}

Anahtar sözcükler:Okulöncesi eğitim, yaratıcı drama, bilim etkinlikleri

\begin{abstract}
This study which has been attempted to determine the effectiveness of creative drama in prescholl science activities over determining the reason-result relations in nature events has been realized controlled pre/posttest experimental model. The study subjects were 14 children in experimental group, 14 children in control group, so totally 28 six years old children. Video and statical analysis were made by using the data. In this study, percent and frequency calculation of the pretest and post test points was made by using video analysis. And also descriptive statical analysis which include standard deviation and aritmetical calculation of pretest and posttest points was made. Mannwhitney-U test was used to determine if the difference between pretest and posttest points are meaningful or not. All statical analysis were made by SPSS 11.5 program. . Findings of the video record and statical analysis can be summarised as following. There is a significant difference between the skills of determining the cause effect of nature events of the experiment group studying learning strategies of creative drama and the control group studying traditional method in science activities in preschool education. The significant difference was in favor of the experimental group. In other words, using creative drama method in preschool science and nature activities enhances the students' skills of determining reason-result relations in nature events.
\end{abstract}

\footnotetext{
${ }^{1}$ Bilim Uzmanı, Eskişehir Zehra Sarar Anaokulu
} 


\section{Keywords: Preschool education, Creative drama, Science activities.}

\section{Giriş}

Gelişme ve öğrenmenin en hızlı olduğu dönem okulöncesi dönemidir. Bu nedenle doğumu izleyen ilk yıllar insan hayatı yönünden son derece önemlidir. Okulöncesi dönemde çocuğun aldığı eğitim, ilerleyen yıllardaki gelişim ve başarısını etkilemektedir. Çocuğun bir sonraki döneme sağlıklı bir şekilde başlayabilmesi, okulöncesi dönemde gereksinimlerinin doğru ve yeterli olarak karşılanmasına bağlıdır. Okulöncesi dönem çocuğu sevgiye, ilgiye, bakım ve beslenmeye, güven duymaya, hareket etmeye, oyun oynamaya, kendisini ve çevresini tanımaya ihtiyaç duymaktadır.

Çocukların nasıl daha kolay ve etkin öğrenebileceklerine ilişkin sorular, çocukların ve öğretmenlerin öğrenme ve öğretim sürecindeki rollerinde değişimlere temel oluşturmuştur. Çocukların kendi öğrenme gereksinimlerinin farkında olması ve bu gereksinimlerini karşılayabilecek olanaklarla eğitilmesi gerçeği, gelişimsel eğitim programlarının oluşturulmasının hareket noktasını oluşturmaktadır. Etkili ve başarılı programlar sadece öğretmenlerinin anlattıklarını ya da gösterdiklerini ezberleme ve tekrarlama yeteneklerini geliştirmeyi değil, problem çözme, eleştirel düşünme, akıl yürütme ve yaratıcılık yeteneklerinin gelişmesine yardımcı olabilen yöntemlerin kullanıldığı programlardır. Etkili programlarda öğrenme, gelişime uygun uygulama ve yaklaşımlar kullanan, zengin ve anlamlı bir içeriğe sahip etkileşim sürecidir (Tuğrul, 2005).

İște tüm bu süreçlere paralel olarak günümüzde her alanda olduğu gibi eğitim alanında da değişmeler ve gelişmeler yaşanmıştır. Çocukların nasıl daha kolay ve kalıcı öğrenebileceği, öğrenmede hangi yöntemlerin kullanılması gerektiği sorularının cevapları, yaratıcı drama yönteminde birleşmiştir.

\section{Drama Kavramı}

Yunanca “dran”dan türetilen drama kavramının Türkçe karş1lığı tam olarak bulunmamaktadır. Dran, yapmak, etmek, eylemek anlamını taşımaktadır. Drama sözcüğü Yunanca Dramenon'daki seyirlik olarak benzetme anlamına daha yakındır ve eylem anlamını taşır. Drama'ya ilişkin diğer kavramlar ise, Amerika'da "yaratıcı drama (creative drama)"; İngiltere'de "eğitimde drama (drama in education)", Almanya'da ise "oyun ve etkileşim (Schulspiel, Spiel un İnteraktion)” dir. (Yıldız, 1997, s. 551).

\section{Eğitimde Yaratıcı Drama}

Günümüzde eğitimden beklenen, bireylerin ezbere dayalı bilgilerle donatılmaları değil, edindikleri bilgileri kendi yaşamlarına yararlı olacak şekilde uygulayabilmelerinin sağlanması, kendi davranışlarının sorumluluğunu üstlenebilen, diğer insanlara karşı da sorumlu olduğunu hisseden bireyler yetiştirilmesidir (Önder, 1999, ss. 85-86). Yani eğitimin öncelikli amac1, öğrenciyi yaşama hazırlamaktır. Drama ile öğrenilenler, yaşama aktarılabilir. Eğitimde yaratıı drama, bilinen, alışılan ve beklenenin dışındakini keşfetme olanağı verir. Öğrenciyi edilgin, dinleyen, izleyen değil, yapan, uygulayan ve sorgulayan konuma getirir (Genç, 2003, s. 204). 
Gerçek yaşamdaki olayların çocuğun içinde yaşadığı ortamda canlandırılması etkili öğrenmeyi sağlamaktadır. Hareket yolu ile öğrenme, sosyal öğrenme, etkileşim yolu ile öğrenme ve keşfederek öğrenme etkili öğrenme yollarındandır. Drama çalışmalarındaki devinimsel hareketler büyük kas gelişimini sağlarken, sosyal olayların canlandırılması ve çocukların birbirlerine model olması sosyal öğrenmeyi, çocukların devamlı birbirleriyle etkileşim içerisinde olmaları etkileşim yolu ile öğrenmeyi sağlar. Çocukların araştırma yeteneğini de geliştiren drama, keşfederek öğrenme işlevine de sahiptir. Çalışmalar sırasında görsel, işitsel ve dokunmaya ilişkin uyarıcılar sağlayabilme niteliğine sahip olan drama yönteminin bu kadar etkili bir yöntem olması, çok sayıda duyuya aynı anda hitap edebilmesinden kaynaklanmaktadır.

Eğitimde düzenli olarak drama etkinliklerine yer vermek, çocuklara soru sorma, araştırma, keşfetme, çözümleme ve değerlendirme becerilerine sahip olma imkanı verir. Çocuklar öğrenme süreci boyunca aktif olduklarından bu süreçte hem neşeli vakit geçirirler hem de öğrenilenlerin kalıcılığının artması sağlanır.

Yaratıcı dramanın doğal olarak ve doğaçlama şeklinde olması, bir metne bağlı kalmamasını ve sergilenmesi için sahneye ihtiyaç duyulmamasını göstermektedir. $\mathrm{Bu}$ nedenle yaratıcı drama çalışmaları provasız, sınıfta ya da uygun ortamlarda; öğrenme yöntemi olarak kullanılmaktadır.

\section{Eğitimde Yaratıcı Dramanın Uygulama Boyutları}

Eğitim öğretimde yaratıcı drama araç ve amaç olmak üzere iki biçimde kullanılır. Araç olarak kullanılmasından, herhangi bir konunun, olayın veya eğitim ünitesinin drama yöntemiyle işlenmesi; amaç olarak kullanılmasından ise, dramanın öğretilmesi anlaşılır. Her ikisinde de çocuğun kişilik gelişimine, iletişim becerilerine yardımcı olmak, drama sanatından haz almasını sağlamak amaçlanır. Yaratıcı drama uygulamalarında yaparak yaşayarak öğrenme, buluş yoluyla öğrenme, sosyal öğrenme, devinim yoluyla öğrenme vb. gibi etkin öğrenme yolları gerçekleştirilir (Öztürk, 2001, s.258).

Drama ile öğrenme, öğretmenlerin anlattığ 1 ve çocukların pasif olarak sadece dinlemesiyle değil, çocukların o esnada geçirdiği yaşantılarla gerçekleşir. Bu yaşantılar sırasında soyut kavramlar, somutlaştırılarak anlamlandırılır.

\section{Eğitimde Yaratıcı Dramanın Aşamaları}

Dramanın bütün uygulama süreçlerinde katılımcılar, bir yandan kendilerini ifade ederken, bir yandan da bulundukları çevreye düşünsel katkı sağlarlar (Öztürk, 2001, s.255). Drama yaşantıları belli aşamaları izlemek durumundadır. Bu aşamalar liderin yapacağı çalışmaya bağlı olarak biçimlendirilir, değiştirilebilir. Söz konusu aşamalar şöyledir:

Isınma Çalışmalart: Bir yaratıcı drama atölyesinde ilk olarak yer verilen çalışmalardır. Tanışma ile başlayan ısınma çalışmaları, güven duyma, uyum sağlama, beş duyuyu kullanma, gözlem yetisini geliştirme gibi amaçlara yönelik etkinliklerdir (Öztürk, 2001, s. 258; Üstündağ, 1998, s. 34). 
Canlandırma: Etkin bir duruma gelmesini sağlamak, etkinliğe geçirmek, geçmiş bir olayı ya da durumu göstererek yaşatmak ya da birinin kılığına, kişiliğine girip onu oynamak olan canlandırma; bir konunun süreç içinde biçimlenip ortaya çıktığı, belirlendiği, biçimlendirildiği tüm oluşum çalışmalarının yapıldığı aşamadır (Adıgüzel, 2006, s. 26).

Değerlendirme: Değerlendirme aşaması kendi içinde üç kısa sorgulamayı sağlar. Bunlar; gözden geçirme, tartışma ve paylaşımdır. Bu aşamada, "ne düşündünüz?", “ne yaşadınız?”, "neler hissettiniz?", “nerede güçlük çektiniz?”, “başka neler olabilirdi?” gibi soruların tartışılarak, yanıtlanması, liderin kendi gözlemlerini katılımcılarla paylaşması esastır.

\section{Okulöncesi Dönemde Yöntem Olarak Yaratıcı Dramadan Yararlanma}

Öğrenme, çocuğun kendi gelişimiyle bütünleşen bir süreçtir. Öğrenmenin amacı "anlamaktır". Çocuk anlamadığı bir şeyi öğrenemez. Drama, yaşantılar aracıllğıyla zihinsel soyutlamaların yapılmasına olanak sağlar. Böylece, yalnızca sözel olarak sunulduğunda ya da yalnızca gösterildiğinde anlaşılabilirliği sınırlı olan yaşantılar, drama sürecinde somut olarak anlam kazanır (Tuğrul, 2003, s. 123).

Drama, çocukların tüm duyularının etkin olarak kullanılmasını sağlar. Çocuklar, drama sürecinde konuşurlar, hareket ederler, bedenlerini, seslerini, duygu ve düşüncelerini kullanırlar, başkalarıyla iletişim içinde olurlar, özgün düşünce, davranış ve somut ürün oluştururlar, eğlenirler. Bu süreç, öğrenme kalitesini doğrudan etkiler. Öğrenmeye etkin ve istekle katılım, öğrenme verimliliğini arttırır (Tuğrul, 2003, ss. 125-126).

Drama, hem bir öğretim yöntemi hem de başlı başına bir eğitim alanıdır. Drama çocuklara;

- Yaratıcılık ve estetik gelişimi

- Eleştirel düşünme yeteneği

- Bağımsız düşünebilme becerisi

- Kendine güven duyma ve karar verme becerileri

- Başkalarını anlama ve hissetme becerisi (Empati kurma)

- Farklı olay, olgu ve durumlarla ilgili deneyim kazanma

- Soyut kavramları ya da yaşantıları somutlaştırma

- Düş gücünün gelişimi

- Başkalarıyla iş birliği içinde çalışma yeteneği

- Etkin iletişim becerilerinin gelişimi

- Yaşanılan dünyayı daha somut olarak görme

- Ahlaki ve kültürel değerlerin gelişimi

- Soyut ve mantıklı düşünmeye yardımcı olma

- Gelişmiş bir oyun kurgusu oluşturma

- Dil gelişimi ve öyküleri anlama becerilerinin gelişimi 
- Farkındalık gelişimi

- Demokrasi ve eşitlik duygusunun gelişimi

- Kendilerinde olan yaratıcı güçlerin açığa çıkması ve gelişimi

- Kaslarını hareket ettiren yeni yöntemleri bulmayı, denemeyi ve bedenini çok yönlü geliştirmeyi

- Problem çözme ve karşılaşılan problemleri yeni bir bakış açısıyla inceleme

- Kendini tanıma-öz farkındalık gelişimi boyutlarında eğitsel ve gelişimsel kazançlar sağlamaktadır (Güven, 2003, Haktanır ve Başer, 1997, Kelner, 1993, McCaslin, 2000, Okvuran, 2005, Ömeroğlu-Turan ve diğerleri, 2003, Öztürk, 2001, Tuğrul, 2003, Tuluk, 2004, Üstündağ, 1998).

\section{Okulöncesi Dönemde Bilişsel Gelişim, Dil Gelişimi ve Drama}

Okulöncesi dönem, bilişsel beceri gelişiminin hızlandığı bir dönemdir. Bilişsel yapının gelişimi ile çocuk; yaşamındaki kişi, nesne, durum ve olaylarla ilgili kavramları tanımaya başlamaktadır. Bunun yanı sıra çocuk drama çalışmaları esnasında düşünme, dinleme, konuşma, anlatma becerilerini de geliştirir.

Özellikle 2-6 yaşlarda çocuk boyut, renk, sayı, miktar, şekil, duyu vb. kavramları geliştirmektedir. 26 yaşlarda çocuk sembolleri konuşmalarında, oyunlarında sıklıkla kullanmaktadır. Nesneleri zihninde canlandırmaktadır. Günlük yaşamlarında karşılaştıkları problemlere çözüm üretebildiği gibi, aynı zamanda kişi, nesne ve olaylar arasında bağ kurabilmektedir. $\mathrm{Bu}$ doğrultuda, yaratıcı drama etkinlikleri çocuğun bilişsel becerilerinin gelişimini doğrudan desteklemektedir. Drama etkinlikleri sırasında çocuklar, düşündüklerini yaşantıya dönüştürmektedir. Bu da çocuklara aktif ve etkin bir öğrenme ortamı sunmaktadır. Böylece çocuklar, yaparak-yaşayarak bilgiyi keşfedebilirler. Ayrıca, çocuklar gerçek nesneleri simgesel anlamda kullanarak, imgelem güçlerini ve yaratıcılıklarını geliştirmekte, kavramlarla ilgili drama ile kısa sürede ve kalıcı şekilde öğrenmektedirler (ÖmeroğluTuran ve diğerleri, 2003, ss. 31-32).

Hayal kurmak ya da bir şeyleri taklit etmek küçük çocukların dünyasının önemli bir parçasıdır. $\mathrm{Bu}$ davranışlar en fazla drama etkinliklerinde gözlemlenir. Drama, çocukların çevrelerini keşfetmelerini sağlarken, muhakeme ve problem çözebilme gibi zihinsel becerilerin gelişmesini de destekler. Farklı drama etkinlikleri içinde çocukların dil gelişimi de artar.

\section{Okulöncesi Eğitimde Fen Etkinlikleri}

Okulöncesi dönemdeki çocuklar meraklı, araştırıcı, hayal güçleri kuvvetli ve sorgulayıcıdırlar. Çocukların bu yöndeki gelişimlerini desteklemek, fen bilgisine ilişkin sağlam temeller oluşturmak amacıyla; onlara araştırabilecekleri, meraklarını giderebilecekleri, neden-sonuç ilişkisini görebilecekleri, çeşitli fikirler öne sürerek tahminlerde bulunabilecekleri firsatlar verilmelidir. (AktaşArnas, 2003, s. 42). 
Okulöncesi çağda çocukların çevrelerini tanıma, etrafta olup bitenleri anlama istek ve ihtiyaçları çok fazladır (Demiral, 1986, s. 163). Okulöncesi çocukların merak ve araştırma duygularını geliştiren, zihinsel yeteneklerini uyaran, ileriki okul yaşamında başarılı olmalarını sağlayan etkinliklerden birisi de fen ve doğa çalışmalarıdır. Fen ve doğa çalışmaları fen bilimlerine ilişkin bilgilerin çocuğa aktarımı değil, çocuğun fen ve doğa olaylarını yaparak-yaşayarak öğrenmesidir (Albayrak, 2000, s. 55).

Tahmin ve çıkarım yapma fen eğitiminde önemli bir bilimsel süreçtir. Tahmin, ne olmasını beklediğimizi söylemeyi ve sonucun ne olabileceği konusunda pek çok genelleme yapmayı içerir. Çıkarım yapma ise; gözlemleri, deneyleri ya da konu ile ilgili mevcut bilgileri esas alarak sonuç ortaya koymadır. Erken çocukluk eğitiminde fen eğitiminin temel amacı, çocuğun daha iyi tahminler ve gözlemleri sonucunda yorumlar yapabilmesidir. Bu amaçla öğretmen çocukların sorgulama, gözlem yapma, test etme ve yorumlama becerilerini geliştirecek çalışmalara yer vermelidir (Aktaş-Arnas, 2002,).

\section{Okulöncesi Dönemde Yaratıcı Dramanın Fen Öğretimi Açısından Amaçları}

Okulöncesi çocukların merak ve araştırma duygularını geliştirici, bilişsel yeteneklerini uyarıcı etkinliklerden biri fen etkinlikleridir. Fen etkinlikleri, fen ve doğa bilimlerine ilişkin bilgilerin çocuğa aktarımı değil, çocuğun fen ve doğa olaylarını yaparak-yaşayarak öğrenmesidir (Gönen ve UyarDalkılıç, 1997, s. 127).

Okulda öğrenilen bilgilerin günlük yaşamla ilişkilendirilebilmesi için yaratıcı drama kullanılması en etkili yöntemlerden biridir. Yaratıcı dramanın fen eğitiminde bir yöntem olarak kullanılmasının öğrenmenin kalıcı olmasına katkısı büyüktür (Anneralla, 1999; Baker, 1996; Duatepe, 2004; O’Hara, 2001; Akt: Akkuş ve Özdemir, 2006).

Fen etkinlikleri yaratıcı drama ile gerçekleştirildiğinde, çocuklar düşündüklerini hayalinde canlandırırlar ve yaratıcı fikirler üretebilirler. Beş duyu organına hitap eden yaratıcı drama yönteminin kullanılmasıyla fen etkinlikleri sırasında anlaşılması en zor konular çocuklar tarafindan kolaylıkla öğrenilebilir.

Okulöncesi dönemde fen etkinlikleri çocuğun tüm gelişim alanlarına katkıda bulunduğu gibi zihinsel gelişim sürecini de hızlandırır. Merak eden, araştıran, keşfeden çocuk, olayların neden-sonuç ilişkisini kavrar. Belirli durumlarda neler olabileceğini ve nedenini keşfetme çocuğun bilime olan ilgisini arttırır. Özellikle yaşanılan doğa olayları bu yıllarda çocuğun merakını uyandıran olaylardır. Fakat bu yaştaki bir çocuk için kavranması zordur. Dramanın fen etkinliklerinde bir öğretim yöntemi olarak kullanılması çocuğun bu olayları kavramasını sağlar. Çocuk drama sırasında yaşayarak ve eğlenerek öğrendiği için bilgilerin kalıcılığı artar, yaşadığı dünyayı daha iyi tanır.

\section{Araştırmanın Amacı}

$\mathrm{Bu}$ araştırma, okulöncesi 6 yaş grubu çocuklarının fen etkinliklerinde doğa olaylarının neden-sonuç ilişkilerini belirleme becerilerinin geliştirilmesinde, yaratıcı dramadan yararlanarak işlenen fen 
etkinliklerinin düz anlatım yöntemiyle işlenen fen etkinliklerine göre daha etkili olup olmadığını sınamak amacıyla gerçekleştirilmiştir. Bu amaçla aşağıdaki sorulara yanıt aranmıştır:

1- Okulöncesi fen etkinliklerinde "gökyüzündeki olayların” neden-sonuç ilişkisini belirlemede, eğitimde yaratıcı drama ve düz anlatım yöntemlerinin etkililiği açısından anlamlı bir fark var midır?

2- Okulöncesi fen etkinliklerinde "yeryüzündeki olayların" neden-sonuç ilişkisini belirlemede, eğitimde yaratıcı drama ve düz anlatım yöntemlerinin etkililiği açısından anlamlı bir fark var mıdır?

3- Okulöncesi fen etkinliklerinde "yeraltındaki olayların" neden-sonuç ilişkisini belirlemede, eğitimde yaratıcı drama ve düz anlatım yöntemlerinin etkililiği açısından anlamlı bir fark var mıdır?

\section{Yöntem}

$\mathrm{Bu}$ bölümde, araştırmanın modeli, denekler, verilerin toplanması, verilerin çözümlenmesi ve yorumlanması açıklanmıştır.

\section{Araştırma Modeli}

Okulöncesi eğitimi fen etkinliklerinde doğa olaylarının neden-sonuç ilişkilerini belirlemede yaratıcı dramanın etkililiğini belirlemeyi amaçlayan bu araştırmanın gerçekleştirilmesinde deneme modellerinden öntest-sontest kontrol gruplu model (ÖSKM) kullanılmıştır. Ayrıca, deneklerle öntest ve sonteste ilişkin yarı yapılandırılmış görüşmeler gerçekleştirilmiş ve videoya kaydedilmiş olan görüşmelerin analizleri yapılmıştır.

\section{Denekler}

Bu araştırmaya, 2007-2008 eğitim öğretim yılı güz döneminde Eskişehir il merkezinde yer alan Yunuskent Anaokuluna devam eden 6 yaş grubundaki çocuklar katılmıştır. Deney ve kontrol gruplarının atanmasında, kura çekilmiş, çekilen kura sonucunda $\mathrm{E}$ şubesi deney grubu, $\mathrm{F}$ şubesi kontrol grubu olarak atanmıştır.

Tablo 1.

Deneklerin Cinsiyete Göre Yüzde ve Frekans Dă̆ılımı

\begin{tabular}{|c|c|c|}
\hline Cinsiyet & Frekans & Yüzde \\
\hline Kız & 10 & 35,7 \\
\hline Erkek & 18 & 64,3 \\
\hline Toplam & 28 & 100,0 \\
\hline
\end{tabular}

\section{Deney ve Kontrol Gruplarının Oluşturulması}

$\mathrm{Bu}$ araştırma kapsamında, deney ve kontrol gruplarındaki çocuklar, öntest puanları açısından denkleştirilmek istenmiştir. Bu amaçla okulda bulunan 6 yaş grubu $\mathrm{C}, \mathrm{E}, \mathrm{F}$ ve $\mathrm{G}$ şubelerine ön test soruları sorulmuştur. E ve F şubelerinin puanları birbirine yakın olduğundan, araştırma için bu iki şube seçilmiştir.

\section{Öğretim Materyalleri}


Öğretim materyallerinin geliştirilmesi sürecinde, çocukların doğa olaylarının neden sonuç ilişkilerini belirlemeye yönelik olarak yaratıcı drama yöntemi doğrultusunda uygulanacak amaç ve kazanımlar belirlenmiştir. Daha sonra bu amaçların çocuklara kazandırılması için uygulanacak etkinlik planları ve etkinlik sırasında kullanılacak olan öğretim materyalleri hazırlanmıştır. Çocuklarla yapılacak olan etkinliklerde resimler, cd'ler, modeller ve maskelerden yararlanılmıştır.

\section{Denel İşlem}

Veri toplama araçları, öğretim uygulaması sırasında kullanılacak plan ve öğretim materyalleri hazırlandıktan sonra, uygulamanın Merkez Yunuskent Anaokulu'nda yapılabilmesi için Eskişehir İl Milli Eğitim Müdürlüğü'nden gerekli izin alınmıştır Deney ve kontrol grupları belirlendikten sonra, deney ve kontrol grubunun öğretmenine araştırmanın konusu ve nasıl yürütüleceğine ilişkin bilgiler verilmiştir. Çocuklar da araştırma konusunda bilgilendirilmiştir. Daha sonra, kontrol ve deney grubuna etkinlik konularıyla ilgili sorular öntest olarak uygulanmıştır.

Araştırmanın niteliği açıklandıktan, bilgi formu öntest olarak uygulandıktan sonra araştırmanın uygulamasına geçilmiştir. 2007-2008 eğitim öğretim yılı güz döneminde, toplam iki haftalık bir süre içinde gerçekleştirilen uygulama süresince, doğa olaylarının neden-sonuç ilişkilerini belirlemeye yönelik toplam 9 oturum gerçekleştirilmiştir. Oturumlarda, gökyüzü olayları, yeryüzü olayları ve yeraltı olaylarıyla ilgili toplam dokuz konuda etkinlikler yapılmıştır. Gök yüzü olaylarıyla ilgili konular; "Kar nasıl oluşur?", "Bulutlar neden hareket eder?” ve "Gece gündüz nasıl oluşur?"dur. Yeryüzü olaylarıyla ilgili konular ise "Toprak nasıl oluşur?”, “Toprak kayması nasıl önlenebilir?” ve "Yerçekimi olmasaydı ne olurdu?"dur. Yer altı olaylarıyla ilgili konular ise "Deprem nasıl oluşur?", "Yanardağ neden patlar?" ve "Yağmur suları toprakta nasıl kaybolur?"dur. Oturumlardaki etkinlikler konunun deneylerle anlatılması ve sonrasında da konuyla ilgili bir drama etkinliğinin uygulanmasından oluşmaktadır. Etkinliklerin deney ve kontrol gruplarında uygulanmasındaki farklılık; deney grubunda etkinlik deney ve açıklamalarla anlatıldıktan sonra drama yöntemi uygulanırken, kontrol grubunda etkinliğin deney ve açılamalarla anlatılıp drama yöntemi kullanılmayarak öğretmen merkezli düz anlatım yöntemi ile bir öğretim gerçekleştirilmesidir. Oturumun sonunda her iki gruba etkinlik konularıyla ilgili sorular son test olarak sorulmuştur.

\section{Veriler ve Toplanması}

Araştırmanın kuramsal temelinin oluşturulması için yerli ve yabancı kaynaklar taranmış, bunun yanı sıra konu uzmanlarından görüş alınmıştır. Araştırma için veri toplama aracı olarak uzman görüşüne sunulan bilgi formu hazırlanmıştır Bilgi formunda gökyüzü, yeryüzü ve yeraltı olaylarıyla ilgili sorulara yer verilmiştir.

Soruların güçlük derecesini belirlemek amacıyla bu sorular, okulöncesi, sınıf öğretmenliği ve fen bilimleri alanından öğretim üyesi, öğretim görevlisi, araştırma görevlisi, okulöncesi öğretmeni, fen bilgisi öğretmeninden oluşan toplam 30 uzman görüşüne sunulmuştur. 20 uzmandan geri dönüt alınmıştır ve bu görüşler sonucunda hangi etkinliklerin uygulanacağı belirlenmiştir. Uzmanlardan gelen dönütlere göre ön test-son testte sorulacak sorular belirlenerek veri toplama aracı olarak bu 
sorulardan ve de etkinlikler sırasında kullanılan materyallerden yararlanılmıştır. Araştırmada ayrıca, gözlemciler arası güvenirlik ve uygulama güvenirliği verileri de toplanmıştır.

\section{Verilerin Çözümlenmesi ve Yorumlanması}

Değerlendirme sürecinde çocukların sorulara verdikleri cevaplar, "doğru cevap, eksik cevap, yanlış cevap ve cevap vermeme" kategorileri kullanılarak değerlendirilmiştir. Bu kategorilerin anlamı şu şekildedir: Doğru cevap: Soru ile ilgili fikirlerin bir kısmını veya tamamını içeren cevapların verilmesi, Eksik cevap: Doğru ancak açıklaması yetersiz olan cevapların verilmesi, Yanlış cevap: Soru ile ilgisi olmayan cevapların verilmesi, Cevap vermeme: Sorunun cevapsız bırakılması, sorunun aynen veya kısmen tekrar edilmesi, bilmiyorum ya da unuttum gibi cevaplar verilmesi. Çocukların verdiği her doğru cevaba 3 puan, her eksik cevaba 2 puan, her yanlış cevaba 1 puan, cevap vermedikleri her soruya da 0 puan verilmiştir.

$\mathrm{Bu}$ çalışmada deney ve kontrol grubuna dahil olan çocukların ön ve son testlerinin karşılaştırılması ile, eğitimde yaratıcı drama yönteminin, okulöncesi fen etkinliklerinde doğa olaylarını neden-sonuç ilişkilerini belirlemeye etkisi istatistiksel açıdan araştırılmıştır. İstatistiksel hesaplamalar deney grubunda 14, kontrol grubunda 14 olmak üzere toplam 28 denek üzerinden gerçekleştirilmiştir. Elde edilen veriler "Mann-Whitney Testi” ile çözümlenmiştir. Gruplar arası karşılaştırmalarda anlamlılık düzeyi 0,05 olarak benimsenmiştir.

\section{Bulgular ve Yorum}

$\mathrm{Bu}$ bölümde, araştırmanın temel amacına uygun olarak araştırma kapsamındaki çocuklardan toplanan verilerin istatistiksel çözümlemeleri ile uygulama sürecinde gerçekleştirilen gözlemlerden ortaya çıkan bulgulara ve yorumlara yer verilmiştir. Araştırmanın amaçlarından olan fen etkinlikleri doğa olaylarının neden-sonuç ilişkisini belirlemede yaratıcı dramanın etkililiğini belirlenmesine yönelik hazırlanmış olan her bir soruya ilişkin deneklerin verdikleri cevapların dağılımı Tablo 2.'de verilmiştir. Ayrıca deneklerin her bir soruya verdikleri cevaplara ilişkin standart sapma ve aritmetik ortalama puanları Tablo 3.'de yer almaktadır.

Tablo 2.

Çocukların Doğa Olaylarına İlişkin Sorulara Verdikleri Cevapların Frekans ve Yüzde Dağılımları

\begin{tabular}{|c|c|c|c|c|c|c|c|c|c|}
\hline $\begin{array}{c}\text { Drama } \\
\text { Yöntemi } \\
\text { Öntest }\end{array}$ & $\begin{array}{l}\text { Doğru } \\
\text { Cevap }\end{array}$ & $\begin{array}{l}\text { Eksik } \\
\text { Cevap }\end{array}$ & $\begin{array}{l}\text { Yanlış } \\
\text { Cevap }\end{array}$ & $\begin{array}{l}\text { Cevap } \\
\text { Yok }\end{array}$ & $\begin{array}{c}\text { Drama } \\
\text { Yöntemi }\end{array}$ & $\begin{array}{l}\text { Doğru } \\
\text { Cevap }\end{array}$ & $\begin{array}{l}\text { Eksik } \\
\text { Cevap }\end{array}$ & $\begin{array}{l}\text { Yanlış } \\
\text { Cevap }\end{array}$ & $\begin{array}{l}\text { Cevap } \\
\text { Yok }\end{array}$ \\
\hline Öntest & $\mathrm{n} \quad \%$ & $\mathrm{n} \quad \%$ & n $\%$ & $\mathrm{n} \quad \%$ & Sontest & $\mathrm{n} \quad \%$ & $\mathrm{n} \quad \%$ & $\mathrm{n} \quad \%$ & $\%$ \\
\hline Soru 1 & & $\begin{array}{ll}1 & 7,1\end{array}$ & $\begin{array}{ll}321,4 \\
\end{array}$ & $10 \quad 71,4$ & Soru 1 & $\begin{array}{ll}4 & 28,6\end{array}$ & $\begin{array}{ll}642,9 \\
\end{array}$ & 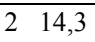 & $\begin{array}{ll}2 & 14,3\end{array}$ \\
\hline Soru 2 & \begin{tabular}{ll|}
1 & 7,1
\end{tabular} & & $\begin{array}{ll}750 \\
\end{array}$ & 42,9 & Soru 2 & $\begin{array}{ll}14 & 100\end{array}$ & & & \\
\hline Soru 3 & & 17,1 & $\begin{array}{ll}6 & 42,9\end{array}$ & 50 & Soru 3 & 1285,7 & 17,1 & 7,1 & \\
\hline Soru 4 & & & $\begin{array}{ll}8 & 57,1\end{array}$ & 42,9 & Soru 4 & $7 \quad 50$ & 642,9 & 17,1 & \\
\hline Soru 5 & & & $\begin{array}{ll}3 & 21,4\end{array}$ & 1178,6 & Soru 5 & $\begin{array}{ll}3 & 92,9\end{array}$ & & 7,1 & \\
\hline Soru 6 & & \begin{tabular}{|l|l|}
2 & 14,3
\end{tabular} & $4 \quad 28,6$ & 57,1 & Soru 6 & $11 \quad 78,6$ & & \begin{tabular}{|l|l}
2 & 14,3 \\
\end{tabular} & 7,1 \\
\hline
\end{tabular}




\begin{tabular}{|c|c|c|c|c|c|c|c|c|c|}
\hline Soru 7 & & 17,1 & 964,3 & 428,6 & Soru 7 & $2 \quad 14,3$ & 857,1 & 214,3 & 214,3 \\
\hline Soru 8 & & 321,4 & 964,3 & $2 \quad 14,3$ & Soru 8 & $8 \quad 57,1$ & 321,4 & 321,4 & \\
\hline Soru 9 & & $\begin{array}{ll}214,3 \\
\end{array}$ & $\begin{array}{ll}6 & 42,9\end{array}$ & $\begin{array}{ll}6 & 42,9\end{array}$ & Soru 9 & 1071,4 & 321,4 & 7,1 & \\
\hline $\begin{array}{c}\text { Düz } \\
\text { Anlatım } \\
\text { Yöntemi } \\
\text { Öntest }\end{array}$ & $\begin{array}{l}\text { Doğru } \\
\text { Cevap } \\
\text { n } \%\end{array}$ & $\begin{array}{c}\text { Eksik } \\
\text { Cevap } \\
\text { n } \%\end{array}$ & $\begin{array}{l}\text { Yanlış } \\
\text { Cevap } \\
n \quad \%\end{array}$ & $\begin{array}{c}\text { Cevap } \\
\text { Yok } \\
\text { n } \quad \%\end{array}$ & $\begin{array}{c}\text { Düz } \\
\text { Anlatım } \\
\text { Yöntemi } \\
\text { Sontest }\end{array}$ & $\begin{array}{l}\text { Doğru } \\
\text { Cevap } \\
n \quad \%\end{array}$ & $\begin{array}{l}\text { Eksik } \\
\text { Cevap } \\
n \quad \%\end{array}$ & $\begin{array}{l}\text { Yanlış } \\
\text { Cevap } \\
\text { n } \%\end{array}$ & $\begin{array}{c}\text { Cevap } \\
\text { Yok } \\
\text { n } \quad \%\end{array}$ \\
\hline Soru 1 & & 17,1 & $\begin{array}{ll}7 & 50\end{array}$ & 642,9 & Soru 1 & $2 \quad 14,3$ & 428,6 & $6 \quad 42,9$ & 214,3 \\
\hline Soru 2 & & & $\begin{array}{ll}8 & 57,1\end{array}$ & 642,9 & Soru 2 & 1071,4 & & 321,4 & $\begin{array}{ll}1 & 7,1\end{array}$ \\
\hline Soru 3 & & 214,3 & 964,3 & 321,4 & Soru 3 & 428,6 & 642,9 & 214,3 & 214,3 \\
\hline Soru 4 & & & 964,3 & 535,7 & Soru 4 & 964,3 & 214,3 & 214,3 & $1 \quad 7,1$ \\
\hline Soru 5 & & & $\begin{array}{ll}7 & 50\end{array}$ & $\begin{array}{ll}7 & 50\end{array}$ & Soru 5 & 1071,4 & & 214,3 & 214,3 \\
\hline Soru 6 & $\begin{array}{ll}17,1 \\
\end{array}$ & $\begin{array}{ll}17,1 \\
\end{array}$ & $5 \quad 35,7$ & $\begin{array}{ll}7 & 50\end{array}$ & Soru 6 & $\begin{array}{ll}8 & 57,1\end{array}$ & $\begin{array}{ll}1 & 7,1\end{array}$ & 428,6 & $\begin{array}{ll}1 & 7,1\end{array}$ \\
\hline Soru 7 & & 214,3 & $\begin{array}{ll}7 & 50\end{array}$ & 535,7 & Soru 7 & & 857,1 & $5 \quad 35,7$ & $\begin{array}{ll}1 & 7,1\end{array}$ \\
\hline Soru 8 & & & $\begin{array}{ll}7 & 50\end{array}$ & $\begin{array}{ll}7 & 50\end{array}$ & Soru 8 & 7,1 & $\begin{array}{ll}7 & 50\end{array}$ & 428,6 & 214,3 \\
\hline Soru 9 & & 321,4 & 642,9 & 535,7 & Soru 9 & 50 & $\begin{array}{ll}535,7 \\
\end{array}$ & & 214,3 \\
\hline
\end{tabular}

Deneklerin öntest ve sontest sorularına ilişkin verdikleri cevapların video kayıtlarının analizleri yapılarak açıklanmıştır. Video analizlerinden hareketle deneklerin öntest ve sontest sorularına verdikleri cevapların

yüzde ve frekansları Tablo 2.'de gösterilmiștir.

Tablo 3.

Deneklerin Öntest-Sontest Sorularına Verdikleri Cevapların Standart Sapma ve Aritmetik Ortalamalarl

\begin{tabular}{|c|c|c|c|c|c|c|c|c|c|}
\hline $\begin{array}{l}\text { So } \\
\text { ru } \\
\text { No }\end{array}$ & Sorular & \multicolumn{2}{|c|}{$\begin{array}{l}\text { Kontrol } \\
\text { Grubu } \\
\text { Öntest }\end{array}$} & \multicolumn{2}{|c|}{$\begin{array}{l}\text { Kontrol } \\
\text { Grubu } \\
\text { Sontest }\end{array}$} & \multicolumn{2}{|c|}{$\begin{array}{l}\text { Deney } \\
\text { Grubu } \\
\text { Öntest }\end{array}$} & \multicolumn{2}{|c|}{$\begin{array}{l}\text { Deney } \\
\text { Grubu } \\
\text { Sontest }\end{array}$} \\
\hline & $\begin{array}{l}\text { Gökyüzüi } \\
\text { Olayları }\end{array}$ & & SS & & ss & & SS & & ss \\
\hline 1 & Kar nasıl oluşur? & 0,64 & $\begin{array}{l}0,63 \\
3\end{array}$ & 1,43 & $\begin{array}{l}0,93 \\
8\end{array}$ & $\begin{array}{l}0,3 \\
6\end{array}$ & $\begin{array}{l}0,6 \\
33\end{array}$ & $\begin{array}{l}1,8 \\
6\end{array}$ & $\begin{array}{l}1,0 \\
27\end{array}$ \\
\hline 2 & $\begin{array}{l}\text { Bulutlar neden } \\
\text { hareket eder? }\end{array}$ & 0,57 & $\begin{array}{l}0,51 \\
4\end{array}$ & 2,36 & $\begin{array}{l}1,08 \\
2\end{array}$ & $\begin{array}{l}0,7 \\
1\end{array}$ & $\begin{array}{l}0,8 \\
25\end{array}$ & $\begin{array}{l}3,0 \\
0\end{array}$ & $\begin{array}{l}0,0 \\
00\end{array}$ \\
\hline 3 & $\begin{array}{l}\text { Gece-gündüz } \\
\text { nasıl oluşur? }\end{array}$ & 0,93 & $\begin{array}{l}0,61 \\
6\end{array}$ & 1,86 & $\begin{array}{l}1,02 \\
7\end{array}$ & $\begin{array}{l}0,5 \\
7\end{array}$ & $\begin{array}{l}0,6 \\
46\end{array}$ & $\begin{array}{l}2,7 \\
9\end{array}$ & $\begin{array}{l}0,5 \\
79\end{array}$ \\
\hline & Toplam & 2,14 & $\begin{array}{l}1,29 \\
2\end{array}$ & 5,64 & $\begin{array}{l}1,78 \\
1\end{array}$ & $\begin{array}{l}1,6 \\
4\end{array}$ & $\begin{array}{l}1,3 \\
93\end{array}$ & $\begin{array}{l}7,6 \\
4\end{array}$ & $\begin{array}{l}1,2 \\
77\end{array}$ \\
\hline \multicolumn{10}{|c|}{ Yeryüzü Olayları } \\
\hline 4 & $\begin{array}{l}\text { Toprak nasıl } \\
\text { oluşur? }\end{array}$ & 0,64 & $\begin{array}{l}0,49 \\
7\end{array}$ & 2,36 & $\begin{array}{l}1,00 \\
8\end{array}$ & $\begin{array}{l}0,5 \\
7\end{array}$ & $\begin{array}{l}0,5 \\
14\end{array}$ & $\begin{array}{l}2,4 \\
3\end{array}$ & $\begin{array}{l}0,6 \\
46\end{array}$ \\
\hline 5 & $\begin{array}{l}\text { Toprak kayması } \\
\text { nasıl önlenebilir? }\end{array}$ & 0,50 & $\begin{array}{l}0,51 \\
9\end{array}$ & 2,29 & $\begin{array}{l}1,20 \\
4\end{array}$ & $\begin{array}{l}0,2 \\
1\end{array}$ & $\begin{array}{l}0,4 \\
26\end{array}$ & $\begin{array}{l}2,8 \\
6\end{array}$ & $\begin{array}{l}0,5 \\
35\end{array}$ \\
\hline 6 & $\begin{array}{l}\text { Yerçekimi } \\
\text { olmasaydı ne } \\
\text { olurdu? }\end{array}$ & 0,71 & $\begin{array}{l}0,91 \\
4\end{array}$ & 2,14 & $\begin{array}{l}1,09 \\
9\end{array}$ & $\begin{array}{l}0,5 \\
7\end{array}$ & $\begin{array}{l}0,7 \\
56\end{array}$ & $\begin{array}{l}2,5 \\
0\end{array}$ & $\begin{array}{l}1,0 \\
19\end{array}$ \\
\hline
\end{tabular}




\begin{tabular}{|c|c|c|c|c|c|c|c|c|c|}
\hline & Toplam & 1,86 & $\begin{array}{l}1,35 \\
1\end{array}$ & 6,79 & $\begin{array}{l}2,60 \\
7\end{array}$ & $\begin{array}{l}1,3 \\
6\end{array}$ & $\begin{array}{l}1,3 \\
36\end{array}$ & $\begin{array}{l}7,7 \\
9\end{array}$ & $\begin{array}{l}1,6 \\
72\end{array}$ \\
\hline \multicolumn{2}{|c|}{ Yeraltı Olayları } & & & & & & & & \\
\hline 7 & $\begin{array}{l}\text { Deprem nasıl } \\
\text { oluşur? }\end{array}$ & 0,79 & $\begin{array}{l}0,69 \\
9\end{array}$ & 1,50 & $\begin{array}{l}0,65 \\
0\end{array}$ & $\begin{array}{l}0,7 \\
9\end{array}$ & $\begin{array}{l}0,5 \\
79\end{array}$ & $\begin{array}{l}1,7 \\
1\end{array}$ & $\begin{array}{l}0,9 \\
14\end{array}$ \\
\hline 8 & $\begin{array}{l}\text { Yanardağ neden } \\
\text { patlar? }\end{array}$ & 0,50 & $\begin{array}{l}0,51 \\
9\end{array}$ & 1,50 & $\begin{array}{l}0,85 \\
5\end{array}$ & $\begin{array}{l}1,0 \\
7\end{array}$ & $\begin{array}{l}0,6 \\
16\end{array}$ & $\begin{array}{l}2,3 \\
6\end{array}$ & $\begin{array}{l}0,8 \\
42\end{array}$ \\
\hline 9 & $\begin{array}{l}\text { Yağmur suları } \\
\text { toprakta nasıl } \\
\text { kaybolur? }\end{array}$ & 0,86 & $\begin{array}{l}0,77 \\
0\end{array}$ & 2,36 & $\begin{array}{l}0,74 \\
5\end{array}$ & $\begin{array}{l}0,7 \\
1\end{array}$ & $\begin{array}{l}0,7 \\
26\end{array}$ & $\begin{array}{l}2,6 \\
4\end{array}$ & $\begin{array}{l}0,6 \\
33\end{array}$ \\
\hline & Toplam & 2,14 & $\begin{array}{l}1,51 \\
2\end{array}$ & 5,36 & $\begin{array}{l}1,59 \\
8\end{array}$ & $\begin{array}{l}2,5 \\
7\end{array}$ & $\begin{array}{l}1,5 \\
55\end{array}$ & $\begin{array}{l}7,6 \\
4\end{array}$ & $\begin{array}{l}1,2 \\
77\end{array}$ \\
\hline
\end{tabular}

Tablo 3.'de gökyüzü olaylarına ilişkin deneklerin her bir soruya verdikleri cevaplara ilişkin aritmetik ortalamalarına bakıldığında öntest kontrol grubunda en yüksek puan soru 3'te elde edilirken, deney grubunda en yüksek puan soru 2'de elde edilmiştir. Sonteste ilişkin puanlarda ise deney ve kontrol grubunun en yüksek puanının soru 2'de elde edildiği görülmektedir. Yeryüzü olaylarına ilişkin deneklerin her bir soruya ilişkin aritmetik ortalamalarına bakıldığında öntest kontrol grubunda en yüksek puan soru 6'da elde edilirken, deney grubunda en yüksek puan soru 4 ve 6'da elde edilmiştir. Sonteste ilişkin puanlarda ise kontrol grubunun en yüksek puanın soru 4'teyken, deney grubunda en yüksek puan soru 5 'ten elde edilmiştir.

Yeraltı olaylarına ilişkin deneklerin her bir soruya ilişkin aritmetik ortalamalarına bakıldığında öntest kontrol grubunda en yüksek puan soru 9'da elde edilirken, deney grubunda en yüksek puan soru 7'de elde edilmiştir. Sonteste ilişkin puanlarda ise kontrol grubunda ve deney grubunda en yüksek puan soru 9'dan, elde edilmiştir. Genel olarak her üç olaya ilişkin öntest ve sontest puanlarına bakıldığında, hem deney hem de kontrol grubunda deneklerin sontest puanlarının öntest puanlarına kıyasla daha yüksek olduğu görülmektedir.

Tablo 4.

Fen Etkinliklerinin Gruba Göre U-Testi Öntest Sonuçları

\begin{tabular}{|c|c|c|l|l|c|c|}
\hline Grup & $\mathrm{n}$ & $\begin{array}{c}\text { Sira } \\
\text { Ortalamas1 }\end{array}$ & $\begin{array}{c}\text { Sira } \\
\text { Toplam1 } 1\end{array}$ & $\mathrm{U}$ & $\mathrm{p}$ \\
\cline { 2 - 7 } & Kontrol & 14 & 15.18 & 212.50 & 88.500 & 0.661 \\
\hline Deney & 14 & 13.82 & 193.50 & & \\
\hline
\end{tabular}

Tablo 4'de, öntest puanlarının gruplara göre farklılık gösterip göstermediğine yönelik yapılan MannWhitney Testi sonucuna göre, sıra ortalaması dikkate alındığında, kontrol grubunda yer alan katılımcılar lehine bir farklılığın olduğu, bu farklılığın ise 0,05 düzeyinde $(U=88,500, p=0,661>0,05)$ anlamlı olmadığı ortaya çıkmıştır. Başka bir deyişle, öntestte almış oldukları puanlar 
karşılaştırıldığında kontrol grubundaki deneklerin, deney grubundaki deneklere kıyasla öntestte daha fazla puan elde etmişlerdir. Ancak, kontrol grubu lehine oluşan bu farkın anlamlı bir fark oluşturmadığ belirlenmiştir. Elde edilen bu sonuca göre deneysel uygulamanın seviyeleri denk olan sınıflarda yapılmış olduğunu söyleyebiliriz.

Tablo 5.

Fen Etkinliklerinin Gruba Göre U-Testi Sontest Sonuçları

\begin{tabular}{|l|l|l|l|l|l|}
\hline Grup & $\mathrm{n}$ & $\begin{array}{l}\text { Sira } \\
\text { Ortalamas1 }\end{array}$ & $\begin{array}{l}\text { Sira } \\
\text { Toplam1 }\end{array}$ & $\mathrm{U}$ & $\mathrm{p}$ \\
\hline Kontrol & 14 & 10.57 & 148.00 & 43.000 & 0.011 \\
\hline Deney & 14 & 18.43 & 258.00 & & \\
\hline
\end{tabular}

Tablo 5'de, sontest puanlarının gruplara göre farklılık gösterip göstermediğine yönelik yapılan Mann-Whitney Testi sonucuna göre, sıra ortalaması dikkate alındığında deney grubunda yer alan katılımcılar lehine bir fark ortaya çıkmıştır. Ortaya çıkan bu farklılığın ise, 0,05 düzeyinde ( $U=43,000$, $\mathrm{p}=0,011<0,05)$ anlamlı olduğu belirlenmiştir. Başka bir deyişle, sontestten almış oldukları puanlar karşılaştırıldığında deney grubundaki deneklerin, kontrol grubundaki deneklere kıyasla sontestte daha fazla puan elde ettikleri görülmüştür. Başka bir deyişle iki haftalık bir deneysel çalışma sonunda, drama yönteminin uygulandığı sınıfta yer alan çocuklarla düz anlatım yönteminin uygulandığı sınıftaki çocukların fen etkinliklerinde doğa olaylarının neden-sonuç ilişkilerini belirleyebilme becerilerine ilişkin puanları arasında anlamlı bir fark bulunmuştur. Bu bulgu, drama yönteminin çocukların fen etkinliklerinde doğa olaylarının neden-sonuç ilişkilerini belirleyebilmelerini arttırmada etkili olduğunu göstermektedir.

\section{Tablo 6.}

Fen Etkinliklerinden Gökyüzü, Yeryüzü ve Yeraltı Olaylarının Gruba Göre U-Testi Öntest Sonuçları

\begin{tabular}{|l|l|l|l|l|l|l|}
\hline & Grup & $\mathrm{n}$ & $\begin{array}{l}\text { Sira } \\
\text { Ortalaması }\end{array}$ & $\begin{array}{l}\text { Sira } \\
\text { Toplamı }\end{array}$ & $\mathrm{U}$ & $\mathrm{p}$ \\
\hline \multirow{3}{*}{ Gökyüzü } & Kontrol & 14 & 16.07 & 225,00 & 76,000 & 0,302 \\
\cline { 2 - 7 } & Deney & 14 & 12,93 & 181,00 & & \\
\hline \multirow{2}{*}{ Yeryüzü } & Kontrol & 14 & 16,04 & 224,50 & 76,500 & 0,311 \\
\cline { 2 - 7 } & Deney & 14 & 12,96 & 181,50 & & \\
\hline \multirow{2}{*}{ Yeralt1 } & Kontrol & 14 & 13,14 & 184,00 & 79,000 & 0,372 \\
\cline { 2 - 7 } & Deney & 14 & 15,86 & 222,00 & & \\
\hline
\end{tabular}

Fen Etkinliklerinden olan Gökyüzü, Yeryüzü ve Yeraltı Olaylarının Gruba göre deneklerin öntest puanlarında farklılık gösterip göstermediğine yönelik yapılan Mann-Whitney U-Testi sonucu Tablo 6'da yer almaktadır. Buna göre sıra ortalaması dikkate alındığında; gökyüzü ve yeryüzü olaylarında 
kontrol grubunda yer alan katılımcılar lehine bir fark ortaya çıkarken, yeraltı olaylarında deney grubu lehine bir fark ortaya çıkmıştır. Ancak, ortaya çıkan bu farklılı̆̆ın 0,05 düzeyinde (Gökyüzü: $\mathrm{U}=76,000, p=0,302>0,05$; Yeryüzü: $U=76,500, p=0,311>0,05$; Yeralt1: $U=79,000, p=0,372>0,05$ ) anlamlı olmadığı görülmektedir.

\section{Tablo 7.}

Fen Etkinliklerinden Gökyüzü, Yeryüzü ve Yeraltı Olaylarının Gruba Göre Deneklerin U-Testi Sontest Sonuçları

\begin{tabular}{|c|l|l|l|l|l|l|}
\hline & Grup & $\mathrm{n}$ & $\begin{array}{l}\text { Sira } \\
\text { Ortalamas1 }\end{array}$ & $\begin{array}{l}\text { Sira } \\
\text { Toplam1 }\end{array}$ & $\mathrm{U}$ & $\mathrm{p}$ \\
\hline \multirow{3}{*}{ Gökyüzü } & Kontrol & 14 & 10,11 & 141,50 & 36,500 & 0,004 \\
\cline { 2 - 7 } & Deney & 14 & 18,89 & 264,50 & & \\
\hline \multirow{2}{*}{ Yeryüzü } & Kontrol & 14 & 13,21 & 185,00 & 80,000 & 0,382 \\
\cline { 2 - 7 } & Deney & 14 & 15,79 & 221,00 & & \\
\hline \multirow{2}{*}{ Yeralt1 } & Kontrol & 14 & 11,46 & 160,50 & 55,500 & 0,045 \\
\cline { 2 - 7 } & Deney & 14 & 17,54 & 245,50 & & \\
\hline
\end{tabular}

Fen Etkinliklerinden gökyüzü, yeryüzü ve yeraltı olaylarında deneklerin aldıkları sontest puanlarının gruplara göre farklılık gösterip göstermediğine yönelik yapılan Mann-Whitney U-Testi sonuçları Tablo 7'de verilmiştir. Buna göre, sıra ortalaması puanları dikkate alındığında; gökyüzü, yeryüzü ve yeraltı olaylarında deney grubu lehine bir fark ortaya çıkmıştır. Ortaya çıkan bu farklılığın 0,05 düzeyinde gökyüzü ve yeraltı olaylarında anlamlı çıkarken (gökyüzü: $U=36,500, p=0,004<0,05$; yeralt1: $U=55,500, p=0,045<0,05$ ), yeryüzü olaylarında 0,05 düzeyinde (yeryüzü: $U=80,000$, $\mathrm{p}=0,382>0,05)$ anlamlı olmadığı görülmektedir. Başka bir deyişle drama yönteminin uygulandığı sınıfta yer alan çocuklarla düz anlatım yönteminin uygulandığı sınıftaki çocukların gökyüzü, yeryüzü ve yeraltı olaylarının neden-sonuç ilişkilerini belirleyebilme becerilerine ilişkin elde ettikleri puanlar karşılaştırıldığında; gökyüzü ve yeraltı olayları puanları arasında anlamlı bir fark bulunurken, yeryüzü olayları arasında anlamlı bir fark bulunmamıştır. Bu bulgu, drama yönteminin çocukların fen etkinliklerinden gökyüzü ve yeraltı olaylarının neden-sonuç ilişkilerini belirleyebilmelerini arttırmada etkili olduğunu göstermektedir.

\section{Sonuçlar, Tartışma ve Öneriler}

$\mathrm{Bu}$ bölümde, araştırmanın bulgularına paralel olarak sonuç, tartışma ve önerilere (uygulamaya yönelik öneriler ve ileri araştırmalara yönelik öneriler) yer verilmiştir.

\section{Sonuçlar}


Araştırmada toplanan verilerin istatistiksel çözümlemesi sonucunda elde edilen bulgular doğrultusunda, aşağıdaki sonuçlar ortaya konmuş ve bu sonuçlara dayalı olarak öneriler geliştirilmiştir.

Okulöncesi eğitimi fen etkinliklerinde öğretim yöntemlerinden yaratıcı dramanın kullanıldığı deney grubu ile düz anlatım yönteminin uygulandığı kontrol grubundaki çocukların doğa olaylarının neden sonuç ilişkilerini belirleme becerileri arasında deney grubu lehine anlamlı bir fark vardır. Bir başka deyişle, yaratıcı dramanın kullanımı, çocukların fen etkinliklerinde doğa olaylarının neden sonuç ilişkilerini belirleme becerilerini geliştirmektedir.

Okulöncesi fen etkinliklerinde "gökyüzündeki ve yeraltı olayların" neden-sonuç ilişkisini belirlemede, eğitimde yaratıcı drama ve düz anlatım yöntemlerinin etkililiğine ilişkin sonuçlara bakıldığında drama yöntemi kullanılarak işlenen gökyüzü ve yeraltı olaylarının, düz anlatım yöntemine göre daha etkili olduğu sonucuna varılmıştır. "Yeryüzündeki olayların" neden-sonuç ilişkisini belirlemeye yönelik eğitimde yaratıcı drama ve düz anlatım yöntemlerinin etkililiğine ilişkin sonuçlara bakıldığında, gruplar arası anlamlı bir fark olmadığı ortaya çıkmıştır. Ancak, deney grubunun sontestten aldığı puanın kontrol grubundan fazla olduğu görülmüştür.

\section{Tartışma}

Deney ve kontrol gruplarına uygulanan sontest sonuçlarına göre, grupların puanları arasında deney grubu lehine anlamlı bir fark görüldü. Okulöncesi eğitimi fen etkinliklerinde doğa olaylarının nedensonuç ilişkilerini belirlemede, yaratıcı drama yönteminin düz anlatım yöntemine göre daha etkili olduğu görüldü.

Yaratıcı drama ile öğretim uygulanan çocuklar, etkinlik sırasında aktif rol alarak, kendilerini ifade edebildiler. Eğlenerek öğrendiler. Çocuğu merkez alan yaratıcı drama uygulanan grupta, çocukların yaratıcı düşüncelerinin gelişmesi sağlandı. Bilişsel, duyuşsal ve devinişsel gelişimierine yönelik gerçekleştirilen drama etkinlikleri ile çocuklar, anlaşılması zor olan kavramları yaşayarak kavradılar. Tüm bunlardan yola çıkarak bu araştırmanın bulguları yaratıcı drama ile öğretimin farklı düzey ve konularda etkililiği üzerine yapılmış diğer çalışma bulgularını destekler niteliktedir.

\section{Öneriler}

Araştırmanın ortaya koyduğu bulgular 1şığında uygulamaya yönelik ve ileri araştırmalara yönelik öneriler belirlenmiştir.

\section{Uygulamaya Yönelik Öneriler}

- Yaratıcı dramanın fen ve doğa etkinliklerinde kullanılabilmesi ile ilgili olarak öğretmenlere yönelik hizmet içi eğitim programları düzenlenebilir.

- Eğitim alanındaki lisans ve lisansüstü programlarda drama dersine yer verilebilir. 
- Okullardaki uygulama ortamlarının fiziksel yetersizliğini giderme çalışmaları yapılarak, araçgereç üretimi ve temini kolaylaştırılabilir.

- Fakültelerde verilen drama derslerini, drama alanında yetişen uzmanlar verebilir.

- Drama konusunda lisansüstü programların sayısı arttırılabilir.

- Okulöncesi eğitimi günlük etkinlik programında drama etkinliklerine daha sık yer verilebilir.

- Okulöncesi öğretmenleri “yaratıcı drama” yöntemini tüm etkinliklerde kullanabilir.

\section{Kaynaklar}

Adıgüzel, H. Ö.(2006). Yaratıcı Drama Kavramı, Bileşenleri ve Aşamaları. Çağdaş Drama Derneği Yaratıcı Drama Dergisi, 1 (1), 17-27.

Akkuş, O. ve Özdemir, P. (2006). Yaratıcı Drama İle Matematik ve Fen Alanındaki Bilim İnsanlarının Yaşam Öykülerine ve Bilime Katkılarına Yeni Bir Bakış. Çağdaş Drama Derneği Yaratıcı Drama Dergisi, 1 (1)59-71.

Aktaş-Arnas, Y. (2003). Fen Eğitimi. Çocuk ve Aile Dergisi, Ekim Sayısı, 42-47, . (2002). Okulöncesi Dönemde Fen Eğitimi, Yaşadıkça Eğitim Dergisi, 76 , 4-6.

Albayrak, H. (2000). Selçuk Üniversitesi Anaokulu/Anasınıfi Öğretmenliği El Kitabı. İstanbul. Haziran Yayınları.

Demiral, Ö. (1986). Okulöncesi Döneminde Fen ve Doğa Çalışmaları, Ya-Pa 4. Okulöncesi Eğitimi Yaygınlaştırma Semineri. Ankara: Ya-Pa Yayınları,.

Genç, N. (2003). Eğitimde Yaratıcı Dramanın Alımlanması. Hacettepe Üniversitesi Eğitim Bilimleri Fakültesi Dergisi, 24, 196-205.

Gönen, M. ve Dalkılıç, N. U. (1997). Anaokuluna Devam Eden 60-72 Aylık Çocuklara Destekleyici Olarak Uygulanan Eğitimde Drama Programının Çocukların Dil Gelişimine Etkisinin İncelenmesi. Okulöncesi Eğitim Sempozyumu. Ankara, Ankara Üniversitesi Basımevi.

Güven, İ. (2003). Drama Öğrenme-Öğretme. Ali ÖZTÜRK(Ed.) Çocukta Yaratıcılık ve Drama. Eskişehir, Anadolu Üniversitesi Açıköğretim Fakültesi Yayınları.

Haktanır, G. ve Başer, İ. (1997). Yaratıcı Drama ve Oyunla Eğitim Uygulamaları. Okulöncesi Eğitim Sempozyumu. Ankara, Ankara Üniversitesi Basım Evi

Kelner, L. B. (1993). The Creative Clasroom. United States of America, Heinemann,

McCaslin, N. (2000). Creative Drama in the Clasroom and Beyond. United States of America, Longman,

Oktay, A. ve diğerleri. (1994). İstanbul'daki Okulöncesi Eğitim Kurumları İle İlgili Bir Durum Tespiti Araştırması. İstanbul Marmara Üniversitesi Ĕ̆itim Bilimleri Dergisi, 6.

Okvuran, A. (2005). Okulöncesi Dönemde Yaratıcı Drama, Çoluk Çocuk Dergisi, Haziran sayısı.

Ömeroğlu-Turan, E. ve diğerleri. (2003). Okul Öncesi Eğitimde Drama Teoriden Uygulamaya (2. Baskl), Ankara, Kök Yayıncılık.

Önder, A. (1999). Eğitici Dramanın Doğru Olarak Uygulanması. Marmara Üniversitesi Anaokulu/Anasınıfi Öğretmeni El Kitabl,. 1. Baskl. İstanbul, Ağustos 
Öztürk, A. (2006). Öğretmen Yetiştirmede Yaratıcı Drama Yöntemiyle İşlenecek Tiyatro Dersinin Öğretmen Adaylarındaki Sözel İletişim Becerilerine Etkileri, H. Ömer ADIGÜZEL (Ed.) Yaratıcı Drama (1985-1998 Yazılar). Ankara, Naturel Yayınc1lı. .(2001). Eğitim-Öğretimde Yeni Bir Yaklaşım: Yaratıcı Drama. Anadolu Üniversitesi Kurgu Dergisi. 18, 251-259.

Tuluk, N. (2004).Yaratıcı Drama. Pivolka, 3 (15), 10-12.

Tuğrul, Belma. (2003). Çocukta Yaratıcılık ve Drama. Ali ÖZTÜRK (Ed.) Okulöncesinde Dramayla Fen ve Matematik Ĕgitimi. Eskişehir, Anadolu Üniversitesi Açık Öğretim Fakültesi Yayınları, .(2005). Çocuk Gelişiminde Anaokulu Eğitiminin Önemi. Bilim ve Aklın Aydınlı̆̆ında Ĕ̈̈itim Dergisi. 6 (62). http://yayim.meb.gov.tr/dergiler/sayi62/tugrul.htm adresinden 31/10/2006 tarihinde indirilmiştir.

Üstündağ, Tülay. (1998). Yaratıcı Drama Eğitim Programının Ögeleri Eğitim ve Bilim/Education and Science dergisi,22 (107), 30-37.

Yıldız, Vesile. (1997). Okul Öncesi Eğitimde Oyunun Kullanılması. İzmir Eğitim Sempozyumu, Nasıl Bir Eğitim Sistemi: Güncel Uygulamalar ve Geleceğe İlişkin Öneriler.

\section{Summary}

\section{The Effectiveness of Creative Drama in Prescholl Science Activities in Determining the} Relationship in Nature Events

\section{Elif ERKOCA AKKÖSE ${ }^{2}$}

The preschool period is one of the periods in which the mental, social and physical development is very fast. Children's experiences in this period are very important for the following periods. The children between 0 and 6 ages are very curious. They always ask questions about the things they live or see. The moments they asked questions are the moments in which the children are ready to learn. At these times it is important to direct them to investigate and explore. Generally information through memorising are presented and learning is realized only by cognitive way. But the children should be included in learning progress and their sensory area must be developed. Creative drama studies in education, covers feelings, thoughts and capabilities of children to learning progress and ensures long term learning. The knowledge gained by creative drama is not the teoritacal information to memorize.

\footnotetext{
${ }^{2}$ Specialist, Eskişehir Zehra Sarar Anaokulu
} 
We can use drama at every stage of education to ensure permanent learning and to make learning enjoyable. Preschoool years are the basis of learning and children can learn easier by living, that's why, creative drama in education is one of the most important teaching methods.

The science activities in preschool period are the first activities by which children meet with science for first time. The activities help children to learn the environment they live and to gain the skills for solving problems. There are mostly abstract event or conceptions in science and activities, and by using creative drama in these activities it will be easy to make the event and conceptions more concrete and make the children learn more easy, enjoyable and permanent.

This study which has been attempted to determine the effectiveness of creative drama in prescholl science activities over determining the reason-result relations in nature events has been realized controlled pre/posttest experimental model.

The study subjects were six years old E and F groups attending Yunuskent Prescholl throughout 2007-2008 academic year in fall semester and there were 14 children in experimental group, 14 children in control group, so totally 28 children participated in this study. Video and statical analysis were made by using the data.

In this study, percent and frequency calculation of the pretest and post test points was made by using video analysis. And also descriptive statical analysis which include standard deviation and aritmetical calculation of pretest and posttest points was made. Mann-whitney-U test was used to determine if the difference between pretest and posttest points are meaningful or not. All statical analysis were made by SPSS 11.5 program. .

Findings of the video record and statical analysis can be summarised as following. There is a significant difference between the skills of determining the cause effect of nature events of the experiment group studying learning strategies of creative drama and the control group studying traditional method in science activities in preschool education. The significant difference was in favor of the experimental group. In other words, using creative drama method in preschool science and nature activities enhances the students' skills of determining reason-result relations in nature events. 